\title{
The Effectiveness of Teaching Factory Implementation in Vocational Education: Case Studies in Indonesia
}

\author{
Ida Nugroho Saputro ${ }^{1,2, *}$, Soenarto ${ }^{1}$, Herminarto Sofyan ${ }^{1}$, Maulida Catur Riyanita ${ }^{2}$, \\ Purwita Sari Rebia ${ }^{3}$, Anggita Listiana ${ }^{4}$

\footnotetext{
${ }^{1}$ Postgraduate Program of Technology and Vocational Education, Universitas Negeri Yogyakarta, Jl. Colombo No. 1 Yogyakarta, Indonesia

${ }^{2}$ Building Engineering Education, Universitas Sebelas Maret, Jl. Ir. Sutami No.36 Surakarta, Indonesia

${ }^{3}$ Graduate Program of Vocational Teacher Education, Universitas Sebelas Maret, Jl. Ir. Sutami No.36 Surakarta, Indonesia
} \\ ${ }^{4}$ Modelling Design and Building Information, Kutasari State Vocational High School 1, Jl. Dr. Soeparno No.29 Banyumas, Indonesia
}

Received July 26, 2021; Revised September 26, 2021; Accepted October 21, 2021

\section{Cite This Paper in the following Citation Styles}

(a): [1] Ida Nugroho Saputro, Soenarto, Herminarto Sofyan, Maulida Catur Riyanita, Purwita Sari Rebia, Anggita Listiana , "The Effectiveness of Teaching Factory Implementation in Vocational Education: Case Studies in Indonesia," Universal Journal of Educational Research, Vol. 9, No. 11, pp. 1841 - 1856, 2021. DOI: 10.13189/ujer.2021.091104.

(b): Ida Nugroho Saputro, Soenarto, Herminarto Sofyan, Maulida Catur Riyanita, Purwita Sari Rebia, Anggita Listiana (2021). The Effectiveness of Teaching Factory Implementation in Vocational Education: Case Studies in Indonesia. Universal Journal of Educational Research, 9(11), 1841 - 1856. DOI: 10.13189/ujer.2021.091104.

Copyright $\odot 2021$ by authors, all rights reserved. Authors agree that this article remains permanently open access under the terms of the Creative Commons Attribution License 4.0 International License

\begin{abstract}
There is a gap between vocational high school graduates' competence with industry's needs. To overcome this, the teaching factory develops an industry-based learning model. Learning in vocational high schools refers to the standards and procedures that apply to the industry and are implemented according to actual industrial conditions. However, factory teaching and learning require careful preparation to meet its parameters. This study used a combination of questionnaires, interviews, and documentation to analyze the implementation of the teaching factory in Indonesia, especially at Vocational High School 5 Surakarta. From the results, it can be seen that seven of the eight parameters have been effectively implemented in the teaching factory. These parameters are management, workshops, training in learning patterns, marketing promotion, products and services, human resources, and legal aspects. Furthermore, it is known that industrial relations parameters are not yet effective enough because the technology transfer and investment have not been implemented between schools and industry. However, some parameters that have been said to be effective are still not evenly distributed for each sub-parameter. Therefore, evaluation and improvement are needed to increase the teaching factory in these vocational high schools.
\end{abstract}

Keywords Vocational Education, Vocational High School, Teaching Factory, Competency-Based Learning

\section{Introduction}

The quality of human resources in Indonesia is still relatively low or below average. This is based on UNDP data in the Human Development Index (HDI) in 2020, which states that Indonesia is ranked 111 out of 189 countries [1]. Besides, Indonesia ranks 65th out of 130 countries based on human resources quality in the 2017 Global Human Capital Report. However, this report explains that Indonesia has a strong view of building human resources potential in the future in all development sub-index [2]. Furthermore, Indonesia's low quality of human resources has caused various social problems, including the relatively high unemployment rate.

Vocational High Schools are expected to reduce unemployment, and at the same time, produce graduates with quality human resources to meet human resources globally. Learning activities must support Vocational High School graduates who can compete in the industrial world so that Vocational High School graduates are ready 
to enter the world of work [3]. It means that Vocational High School graduates must have the knowledge, skills, and attitudes needed by the industrial world [4]. Nevertheless, there is a mismatch between the theories learned in schools and the conditions of practice in the industrial world [5]. It is one of the factors causing the high unemployment rate in Indonesia. According to the Central Bureau of Statistics, the number of unemployed figures in Indonesia as of February 2020 is 6.88 million people. The largest number of unemployed comes from Vocational High School graduates of 8.49\% [6].

In this case, vocational students prepared to work in specific fields are the biggest contributor to unemployment. Through the Ministry of Education and Culture, the government strives to improve human resources' quality to face global competition. According to the Central Bureau of Statistic's empirical observations in 2012 , the problem of preparing vocational high school graduates as a workforce is the gap between vocational high school graduates' competence and the industry's needs. The vocational high school graduates are still weak in the soft skills aspect [7].

Vocational High Schools are required to form students with good soft skills and hard skills, and Vocational High Schools can achieve this by improving the learning process's quality. The improvements made can be in the form of practices applied in industry, preparing competent teachers, following industry developments, and improving facilities or industrial cooperation [5]. The government has attempted several innovations in this case, including revitalizing the existing school curriculum [8]. Another development process in schools is the provision of adequate facilities and infrastructure, as stated in Regulation of the Minister of Education and Culture of the Republic of Indonesia Number 40 of 2008 concerning Standard of Facilities and Infrastructure for Vocational High Schools/Madrasah Aliyah Vocational Schools (SMK/MAK) [9], regarding the Standard of Facilities and Infrastructure, as well as the formation of a good organizational structure and the provision of competent and appropriate teaching staff. To deal with it, an approach model was developed in a teaching factory to overcome and encourage these things.

Teaching factory is an industry-based learning model in which the learning concept in vocational high schools refers to the standards and procedures that apply to the business and the industrial world and is implemented according to the actual industrial conditions [10], [11]. The cooperation between vocational high schools and the business and industrial world is still quite weak due to the limited quantity of equipment and the learning environment that is not suitable for the company and industrial world environment [3]. One of the teaching factory program's main objectives is to improve graduates' vocational high school competence under the industrial world's needs [11], [12]. It can strengthen industrial competitiveness and reduce the gap between workers and industry [13]. It is supported by Louw \& Deacon [14], which revealed that the teaching factory effectively increased students' productive competence. Some of the competencies expected through this teaching factory's application include expertise in psychomotor, affective/attitude, and the ability to think critically and solve problems [12], [14]. So, it is hoped that vocational high schools will produce competent graduates in terms of skills, productivity, and have a good attitude.

Teaching factory requires thorough preparation because all learning activities adapt and adopt quality standards and work procedures in the industry [10], [15]. It can be related to the finding of things that need to be improved in teaching factory learning activities are the learning process in which skills are more adapted to basic work standards [13]. It is in line with one of the parameters for implementing the teaching factory, namely training learning patterns. The learning carried out is directed at industry-based learning [16], [17].

Departing from these problems, the Directorate of Vocational High School Development (2017) created a teaching factory development program. Teaching factory is a product and service-based learning model in vocational high schools that refer to industry standards and procedures and is carried out in an atmosphere like in industry [19], [20]. Implementing the Teaching factory at vocational high schools can be carried out if all parameter aspects get high achievement scores. The teaching factory application parameters are the basis for the preparation of learning programs. These parameters include management, workshops, training learning patterns, marketing promotion, products and services, human resources, and industrial relations [18]. According to the Ministry of Education and Culture [21], the problems that often arise in teaching factory activities are the lack of teacher knowledge in the industry and the human resources. Also, to prove the achievement of the ideal conditions for teaching factory, it includes several aspects, one of which is the legal aspect [22]. This study examines the parameters of applying teaching factory and legal aspects in Vocational High Schools to determine how this teaching factory's implementation has been carried out, especially case studies in Indonesia.

\section{Literature Review}

\subsection{Competency-Based Learning}

Competency-based learning (CBL) is a result-centered and learner-centered form of teaching. They are directed to develop knowledge, understanding, abilities, values, attitudes, and interests to produce the expected abilities/competencies [23].

There is a difference between traditional learning with CBL, which is explained in table 1 . The difference occurs in almost every variable of the Education program. 
Table 1. Differences between traditional learning and CBL [24]

\begin{tabular}{|c|c|c|}
\hline \multirow{2}{*}{ Variables } & \multicolumn{2}{|c|}{ Educational Program } \\
\cline { 2 - 3 } & Structure and process based & Competency-based \\
\hline Driving force for curriculum & Responsibility for content & Responsibility for content \\
\hline Driving force for the process & Teacher & Learner \\
\hline Path of learning & Hierarchical (teacher $\Rightarrow$ student) & Teacher and students \\
\hline Responsibility for content & Teacher & Knowledge application \\
\hline The goal of the educational encounter & Knowledge acquisition & Multiple objective measures ("evaluation portfolio") \\
\hline Typical assessment tool & Single subjective measure & Authentic (mimics real tasks of the profession) \\
\hline Assessment tool & Proxy & "In the trenches" (direct observation) \\
\hline Setting for evaluation & Removed (gestalt) & Criterion-referenced \\
\hline Evaluation & Norm-referenced & Emphasis on formative \\
\hline Timing of assessment & Emphasis on summative & Variable time \\
\hline Program completion & Fixed time & Nent) \\
\hline
\end{tabular}

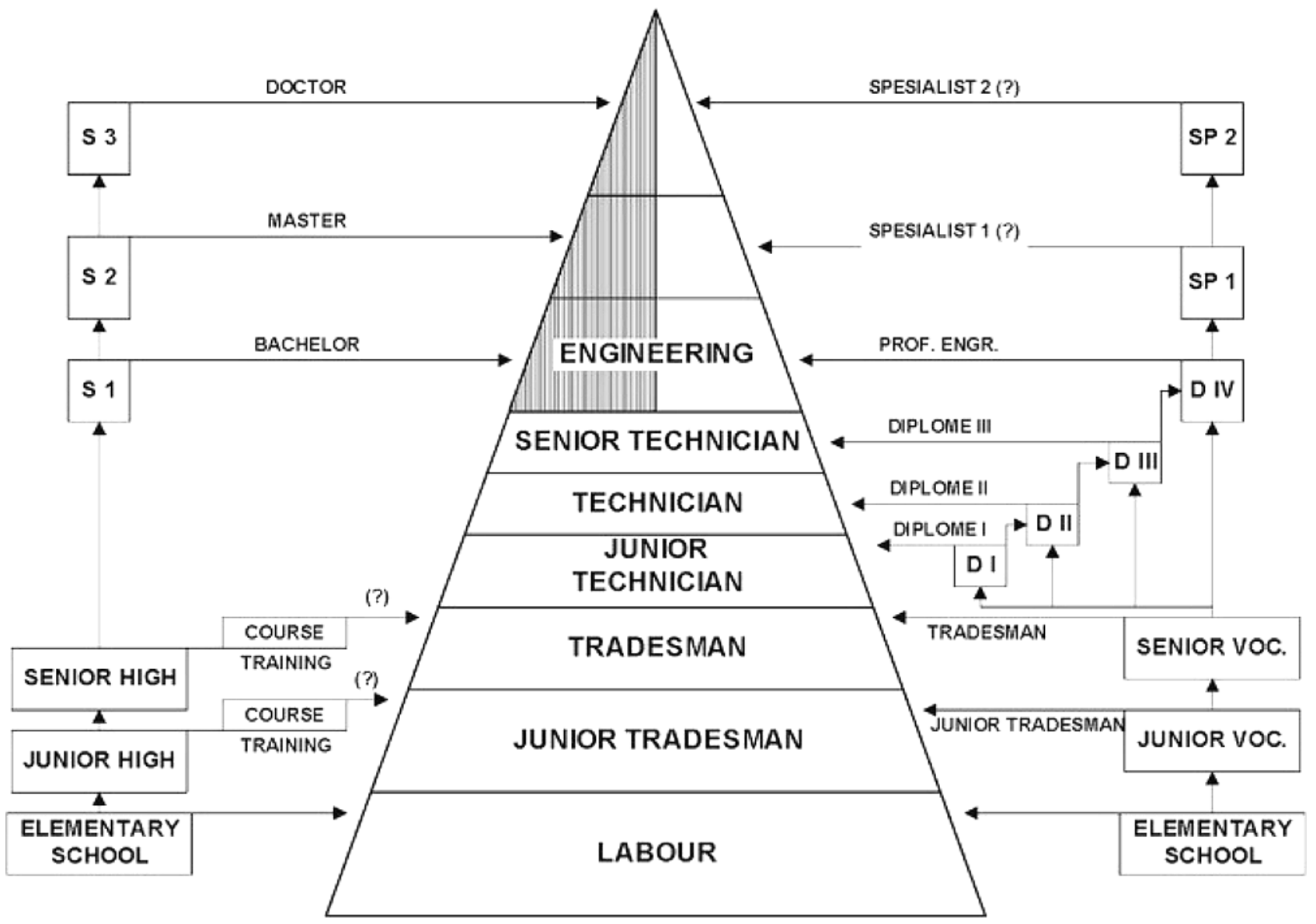

III = R \&D, ENGINEERING \& DESIGN, INOVATION

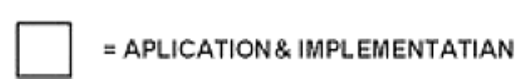

Figure 1. The school-level pyramid of work and education [5]

\subsection{Vocational Education}

Vocational education is an important factor in maintaining competitiveness among manufacturing countries such as Germany [25]. In Indonesia, Vocational Education is called SMK (Sekolah Menengah Kejuruan), 
which provides formal education at the secondary education level with various skill programs such as automotive, machinery. SMK level is included in levels 3 to 6 from below, according to figure 1 [5].

\subsection{Teaching Factory}

Teaching Factory (TF) has emerged as a promising paradigm for manufacturing education. It operates as a geographically non-anchored learning "space" linking remote engineering teams and students working together on real-life projects [3]. The Teaching Factory Paradigm provides a real-life environment for engineering students to develop their skills and competencies by engaging them directly in real-life industry challenges. Using modern digital technology and tools, combined with relevant educational approaches, a two-way knowledge communication between academia and industry is formed, aiming to mutually benefit both stakeholders [11].

The factory-to-classroom concept is one example of the teaching factory, which aims to transfer environmental and factory conditions to the study room. This learning provides the opportunity for students to gain knowledge with various kinds of learning layouts, shown in figure 2 [26].

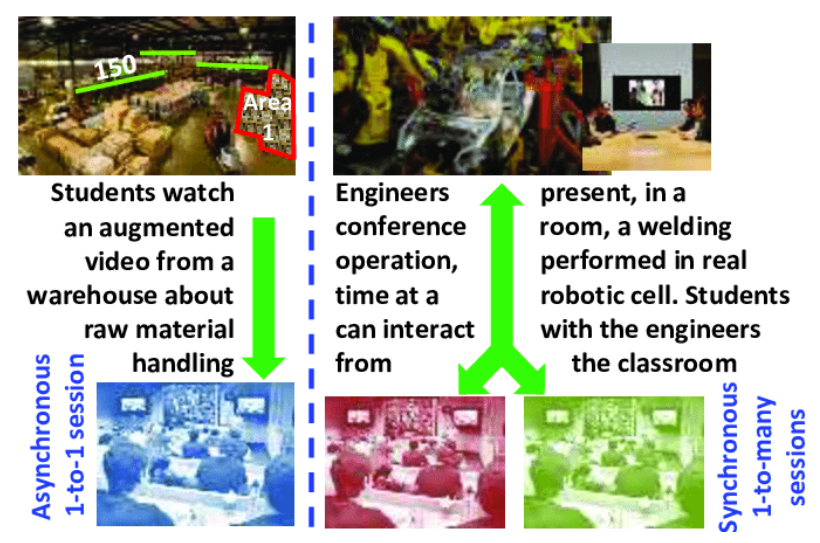

Figure 2. Layout Teaching Factory [26]

\section{Method}

This study is quantitative and qualitative research by combining the questionnaires and documentation methods. The questionnaire method in the form of a closed-answer questionnaire will help respondents answer questions quickly. This questionnaire uses an assessment with a Likert scale as a reference in determining the value of the instrument's answer. Each instrument item has five answer gradations. This scale ranges from very positive, neutral to very negative responses.

The following method used is the documentation method. This technique is carried out to gather information about the parameters of training learning patterns and human resources at State Vocational High School 5 Surakarta, especially in Construction and Property Technology Expertise. This research's documentation is in lesson plans, practical job sheets, photos of students' practical learning activities, and pictures of research activities.

The population in this study includes all layers in State Vocational High School 5 Surakarta, which includes 2.528 teachers and students. With the wide distribution of the population in this study, the researchers took the sample using the random sampling method with 345 samples. The resulting research samples used were all teachers and students in class XI in construction and property technology expertise at State Vocational High School 5 Surakarta. The variables used to refer to the teaching factory parameters set in the Teaching Factory Management are described in table 3. The study's parameter aspects are divided into several measurement indicators referred to in two methods. The research flow uses descriptive quantitative methods with two data collection methods through the teaching factory parameter, as shown in figure 3 about the research procedure. According to the ratio of effectiveness and level of achievement, the research measurement refers to the research and development agency of the Ministry of Home Affairs regarding the concept of effectiveness with the standards described in table 2, according to the ratio of effectiveness and level of achievement [27].

Table 2. Standard Measures of Effectiveness Following the Research and Development Standards of the Ministry of Home Affairs

\begin{tabular}{|c|c|}
\hline Effectiveness Ratio & Achievement Level \\
\hline Under 40 & Very Ineffective \\
\hline $40-59,99$ & Ineffective \\
\hline $60-79,99$ & Effective enough \\
\hline Over 80 & Very effective \\
\hline
\end{tabular}

Source: [27] 
Table 3. Teaching Factory Parameter

\begin{tabular}{|c|c|}
\hline Parameter Aspect & Measurement Indicators \\
\hline \multirow{7}{*}{ Learning Patterns Training } & Learning Implementation Plan (RPP) and LKS (Job sheet) \\
\hline & Practice Materials \\
\hline & Practice Basis \\
\hline & Implementation of Education and Training \\
\hline & Entrepreneurship \\
\hline & Activities of the teacher/instructor \\
\hline & Based on Corporate Culture \\
\hline \multirow{6}{*}{ Human Resources } & Teaching factory competencies \\
\hline & The number and suitability of human resources to run the teaching factory \\
\hline & Motivation \\
\hline & Innovation \\
\hline & Team Work \\
\hline & Training for internal personnel \\
\hline \multirow{4}{*}{ Laboratory } & Equipment \\
\hline & Governance of Tool Use \\
\hline & $\mathrm{MRC}$ \\
\hline & Workshop/Layout \\
\hline \multirow{4}{*}{ Marketing-Promotion } & Communication media for the teaching factory \\
\hline & Brochures/leaflets/other facilities (website, CD, etc.) \\
\hline & Mockups/sample products/models \\
\hline & Market Reach \\
\hline \multirow{5}{*}{ Product-Service } & Products/services for internal needs \\
\hline & Market Acceptability \\
\hline & Delivery \\
\hline & Quality \\
\hline & Quality Control \\
\hline \multirow{5}{*}{ Management } & Financial administration \\
\hline & Organizational structure and job desk \\
\hline & Performance and workflow SOPs \\
\hline & Leadership \\
\hline & The impact of teaching factory on institutions and the environment \\
\hline \multirow{4}{*}{ Industry relation } & Form of cooperation \\
\hline & Project work \\
\hline & Technology transfer \\
\hline & Investments by industry \\
\hline Legal Section & Legal Section \\
\hline
\end{tabular}

Source: [18], [22] 


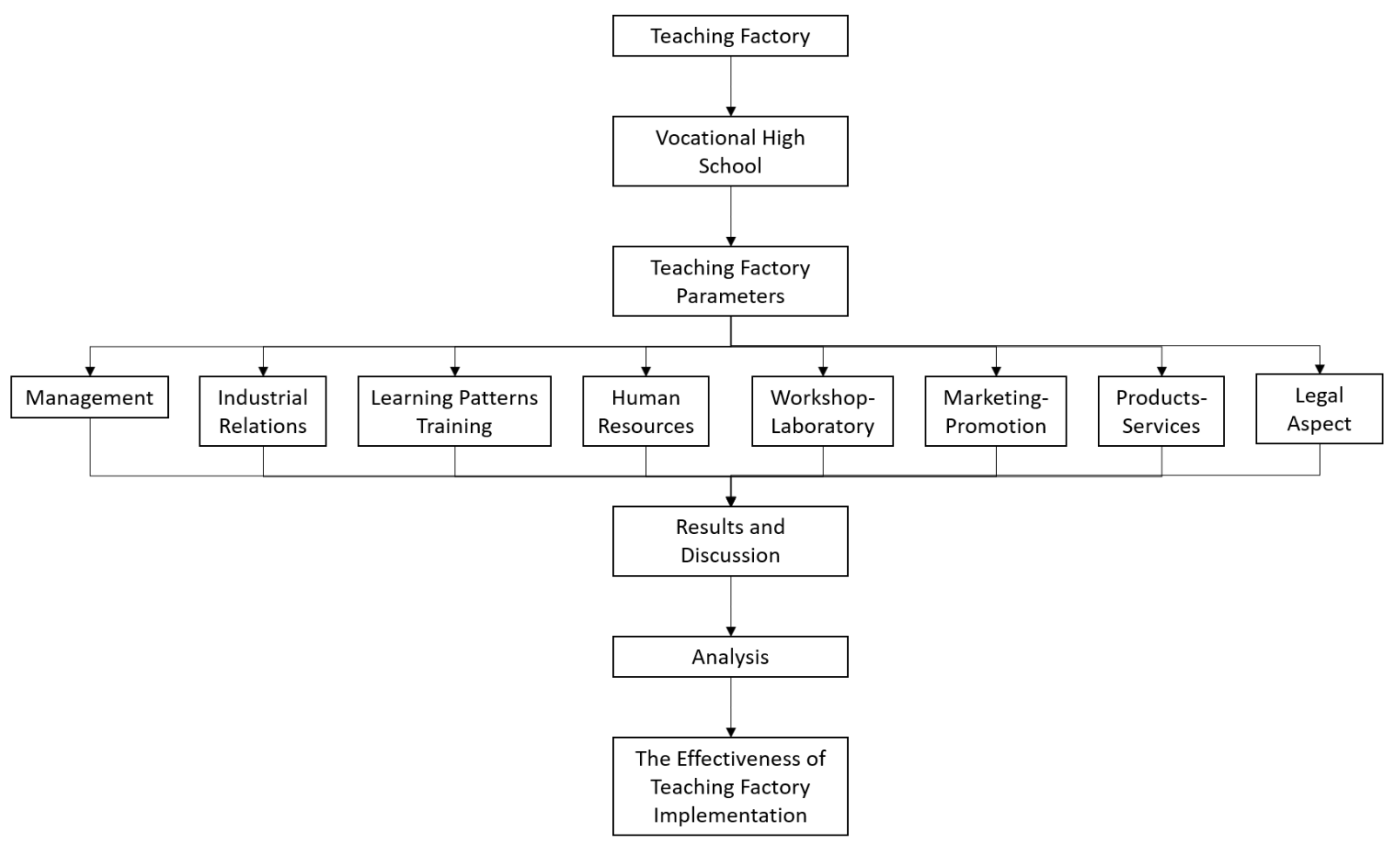

Figure 3. Research Schematic Diagram

Figure 3 explains how various parameters influence the implementation of the teaching factory at the Vocational High School. In this research, the eight influencing parameters were examined quantitatively and qualitatively through questionnaires and documentation methods and analyzed using standard measures of effectiveness. The results obtained are reinforced by observations made from the documentation method to conclude the implementation of the teaching factory that has been carried out.

\section{Result and Discussion}

This study aims to evaluate the parameters that affect the implementation of the teaching factory at Vocational High School. These parameters include management parameters, industrial relations parameters, learning pattern training parameters, human resources parameters, laboratories parameters, marketing promotion parameters, product-service parameters, and legal aspects. These various parameters were analyzed quantitatively and qualitatively to determine the value of the effectiveness of the implementation of the teaching factory, especially the case study in Indonesia, namely at Vocational High School 5 Surakarta. This aims to review and evaluate the implementation of the teaching factory carried out as well as a reference in improving the system that has been carried out.

\subsection{Management Parameters}

Based on the questionnaire results regarding management parameters, the effectiveness average was 76.667 , which is considered quite effective. From these results, it can be stated that the implementation of the teaching factory in terms of management in the field of expertise at State Vocational High School 5 Surakarta is effective.

This is shown in each sub-parameter in management parameters following the teaching factory implementation standards according to the Directorate of Vocational High School Development [18]. The financial administration is in accordance with accounting standards. There is already an organizational structure in each production unit according to industry principles but is still no description of the job desk for each division. The performance and workflow operational standards have been running consistently in the production unit, but there are no written performance and workflow operational standards. The school has provided knowledge about the teaching factory learning model and the benefits of the teaching factory learning model in Vocational High School. The teaching factory activities have an impact on Vocational High School both in terms of facilities and infrastructure. Furthermore, the teachers and students support the teaching factory activities at State Vocational High School 5 Surakarta. It can be seen in figure 4, which shows the mean results of each measurement aspect in management parameters. From the results, it can be concluded that the teaching factory's performance in the field of construction and property technology expertise in State Vocational High School 5 Surakarta in terms of management has been effective. 


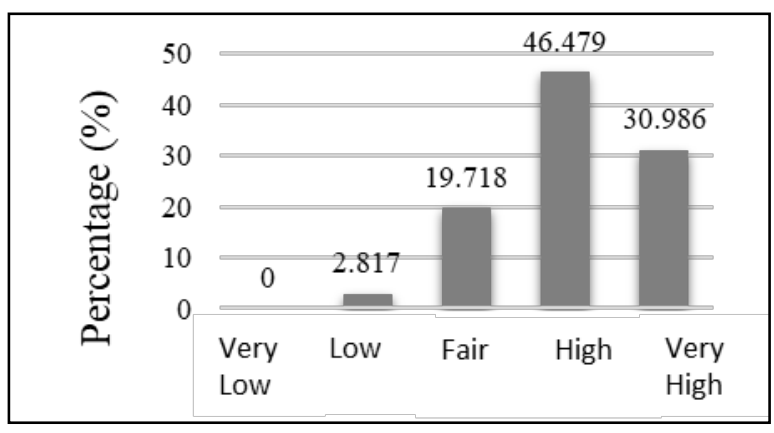

(a) Financial Administration

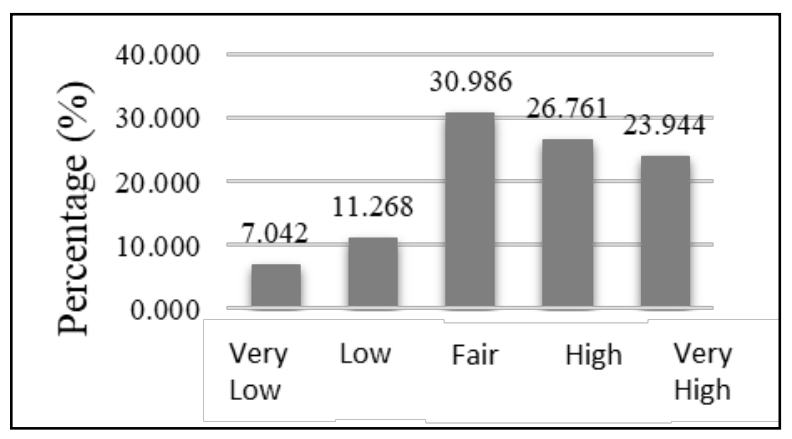

(c) Performance and Workflow Operational Standards

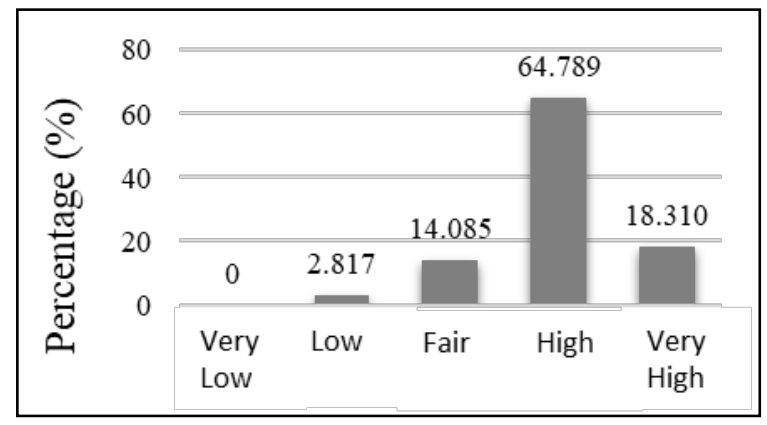

(e) Impact of Teaching Factory on Institutions

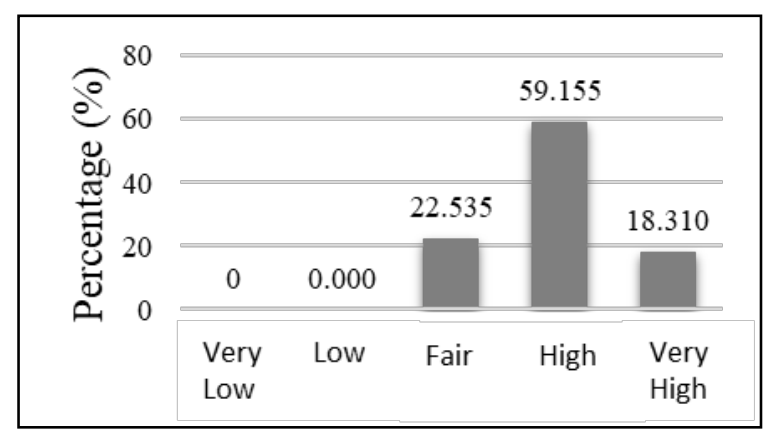

(b) Organizational Structure and Job Desk

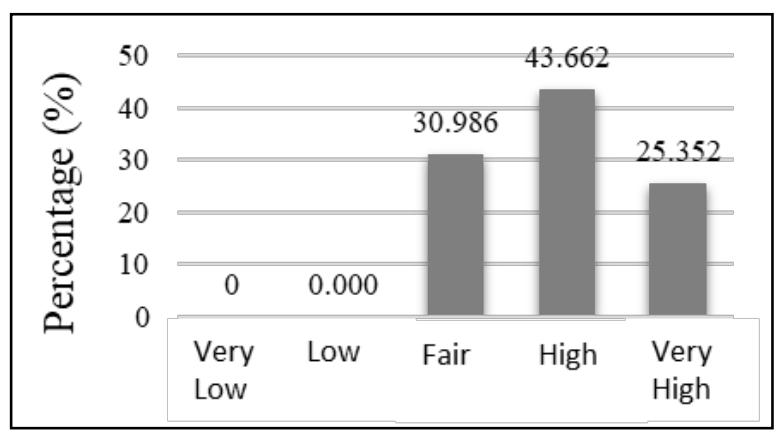

(d) Implementation of Education and Training

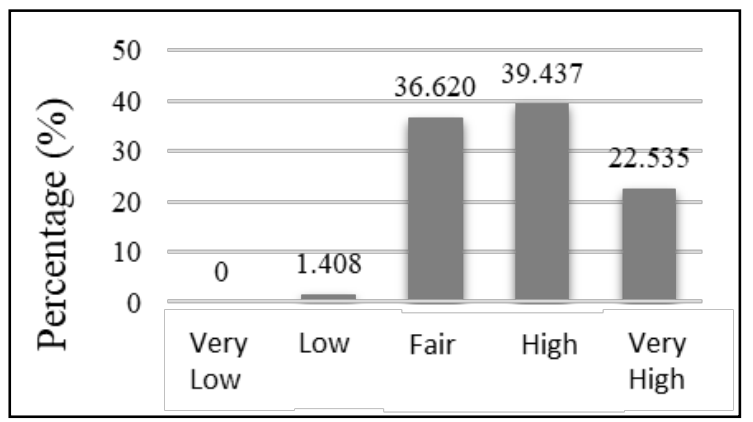

(f) Impact of Teaching Factory on the Environment

Figure 4. Management Parameters

\subsection{Industrial Relation Parameter}

Based on the questionnaire results regarding the relationship parameters, the mean effectiveness is 59.009 , which is included in the level of ineffective achievement. From these results, it can be stated that the implementation of a teaching factory in terms of industrial relations in the field of expertise at State Vocational High School 5 Surakarta is not adequate.

This is shown in each sub-parameter in the industrial relations parameter, and some are not following the teaching factory implementation standards according to the Directorate of Vocational High School Development [18]. The transfer of technology and investment by industry in the field of expertise does not exist because the form of cooperation is still not meeting industrial needs. But for the sub-parameters of the state of collaboration, the area of expertise has collaborated with outside industries in the form of apprenticeship, Memorandum of Understanding (MoU), and learning activities, especially in practice, are based on project work. It can be seen in figure 5, which shows the average results of each measurement aspect in the parameter relationship industry. From the results, it can be concluded that the teaching factory's performance in the field of construction and property technology expertise at State Vocational High School 5 Surakarta in terms of industrial relations is not effective. 


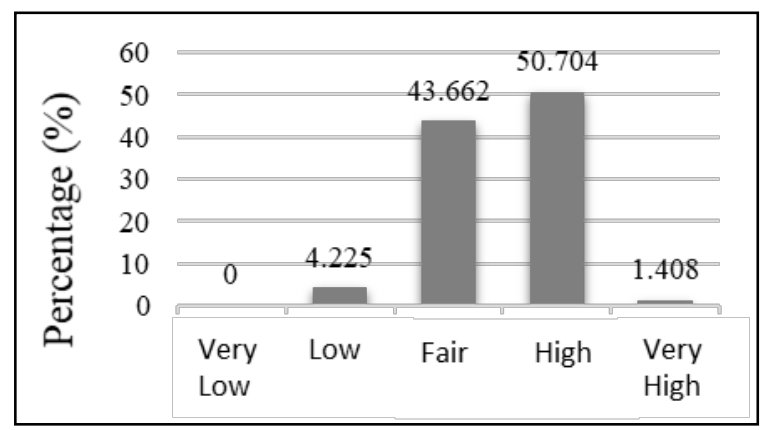

(a) Form of cooperation

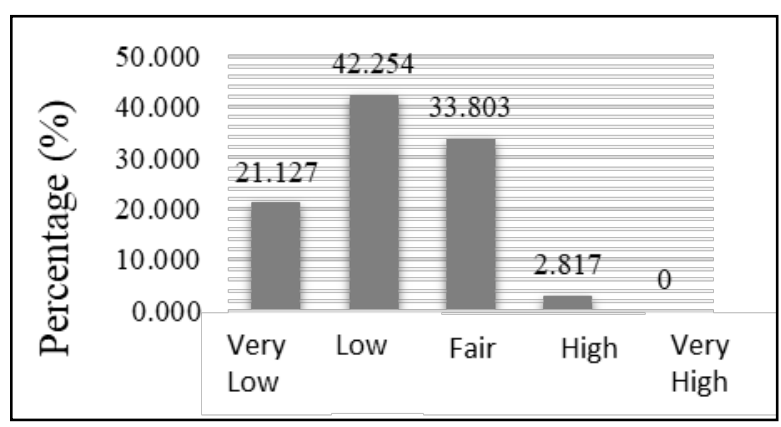

(c) Technology Transfer

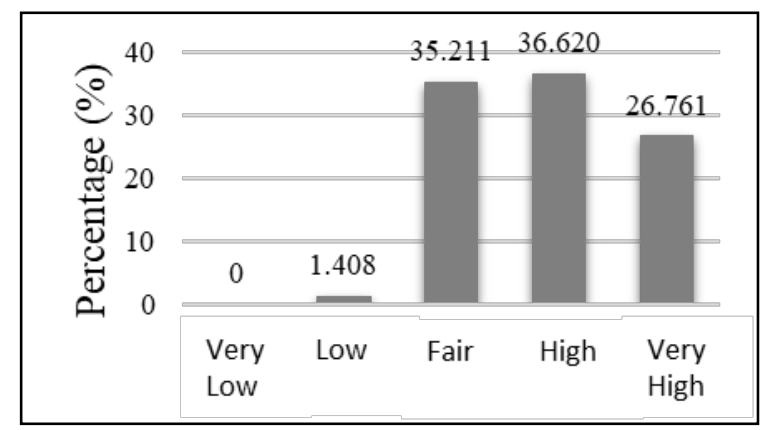

(b) Project Work

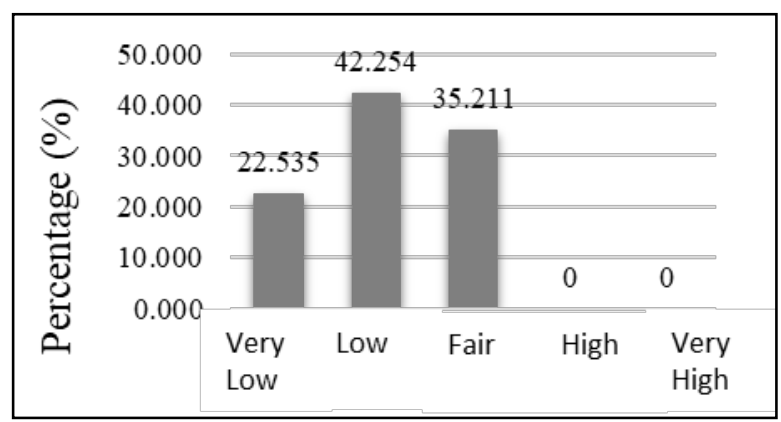

(d) Investment by Industry

Figure 5. Industrial Relations Parameter

\subsection{Learning Pattern Training Parameters}

The questionnaire results regarding the average effectiveness on the training learning pattern parameters were 73.70, which was included in the level of achievement as quite effective.

It is evidenced by the parameters of the training learning pattern that have been directed at industry-based learning and where each sub parameter is following the teaching factory implementation standards contained in the Directorate of Vocational High School Development [18]. The Learning Implementation Plan (RPP) and Student Worksheet (LKS) or job sheet have been made to achieve Competency Standards (SK) and Basic Competencies (KD) following the demands of the curriculum. Furthermore, the curriculum has not been synchronized with the industry, and students get job sheets given by the teacher when students are about to carry out practical activities. Students are allowed to calculate material requirements. The practice results are suitable for sale and are under the buyer's orders, but sometimes there are obstacles to fulfilling practical materials. Students' products can be a source of income, but the quality of the products produced is still lacking in terms of finishing. The teaching factory teaching makes students familiar with industrial conditions through practical activities and industrial work practices. Students have not been fully involved in entrepreneurial activities. The teacher has carried out the main task and function as a teacher and assists students in completing orders if there are obstacles in production activities; practical activities are like the industry's atmosphere and work ethic. It can be seen in figure 6 , which shows the average results of each measurement aspect in the parameters of the training learning pattern. From the results, it can be concluded that the implementation of a teaching factory at State Vocational High School 5 Surakarta in the Expertise of Construction and Property Technology in terms of pattern training learning has been effective. 


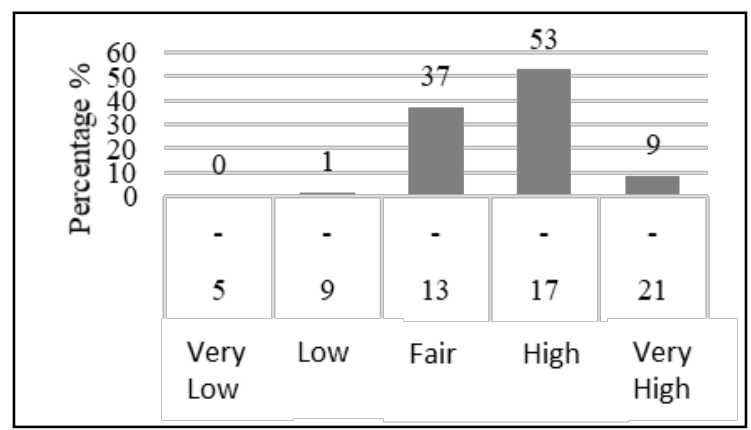

(a) Learning Implementation Plan (RPP) and Student Worksheet (LKS) Job sheet

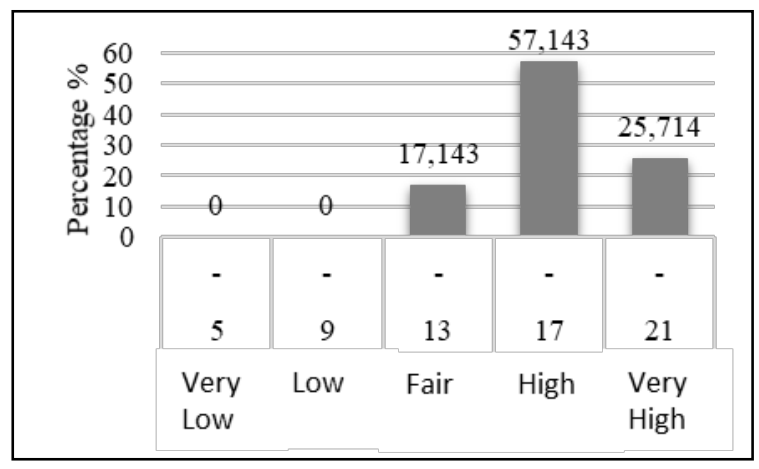

(c) Practice basis

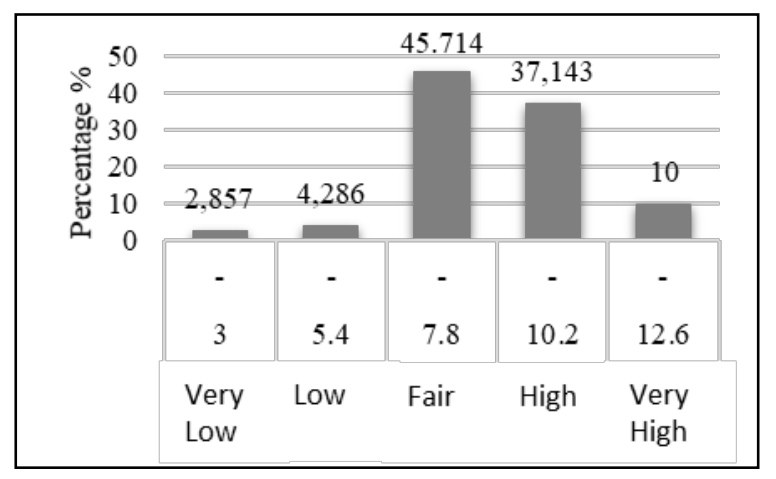

(e) Entrepreneurship

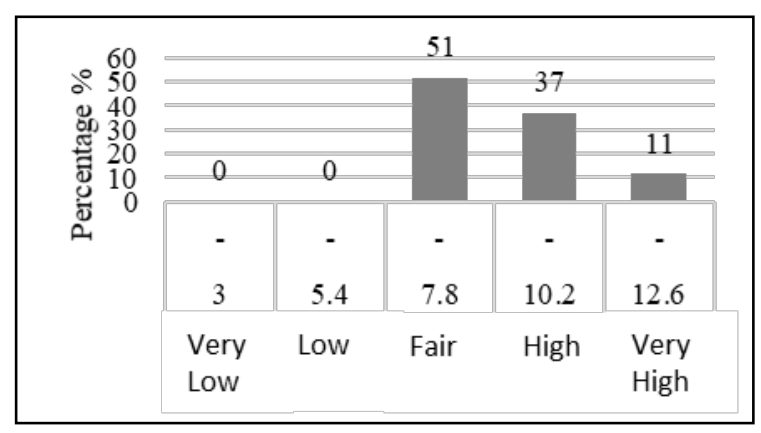

(b) Practice Materials

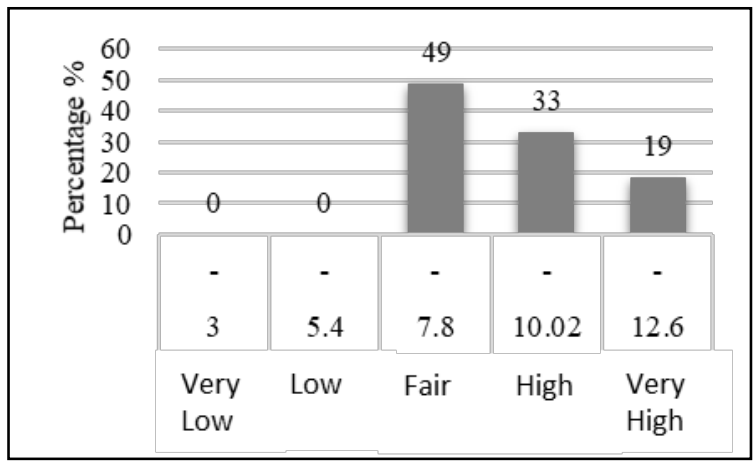

(d) Implementation of Education and Training

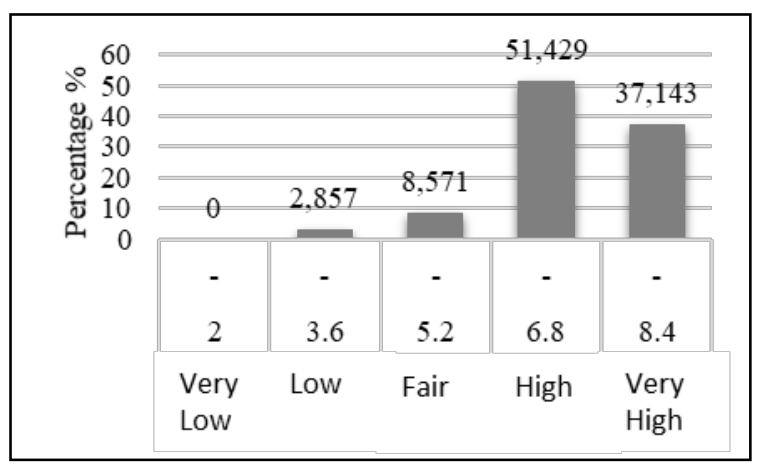

(f) Instructors

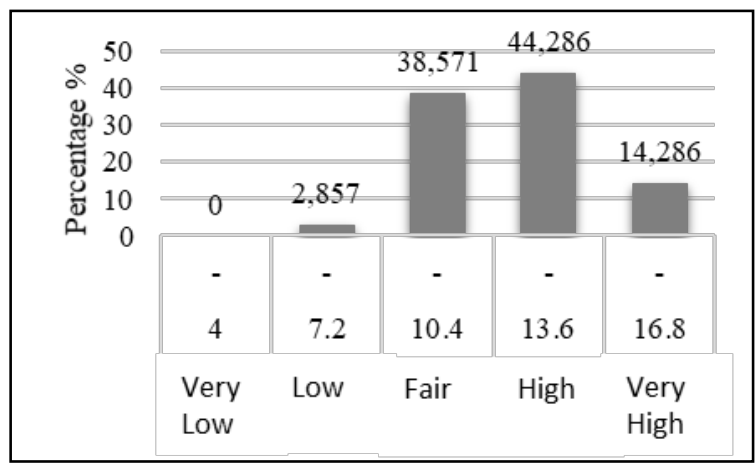

(g) Corporate Culture Background

Figure 6. Training Learning Pattern Parameter 


\subsection{Human Resources Parameters}

Based on the questionnaire results, the average effectiveness of human resource parameters is 70.35, which is included in the achievement level as quite effective.

In human resource parameters, each sub parameter follows the teaching factory implementation standards in the Directorate of Vocational High School Development [18]. The teacher has detailed the products to be made into learning competencies and remedial. The teachers' and student's ratio for theoretical learning are sufficient, but the percentage of students and teachers in practical learning is still lacking. In this case, the distribution of

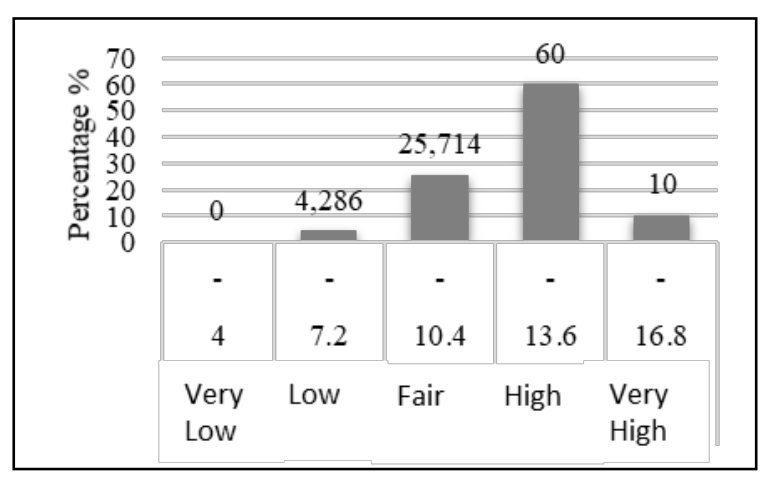

(a) Teaching Factory Competence

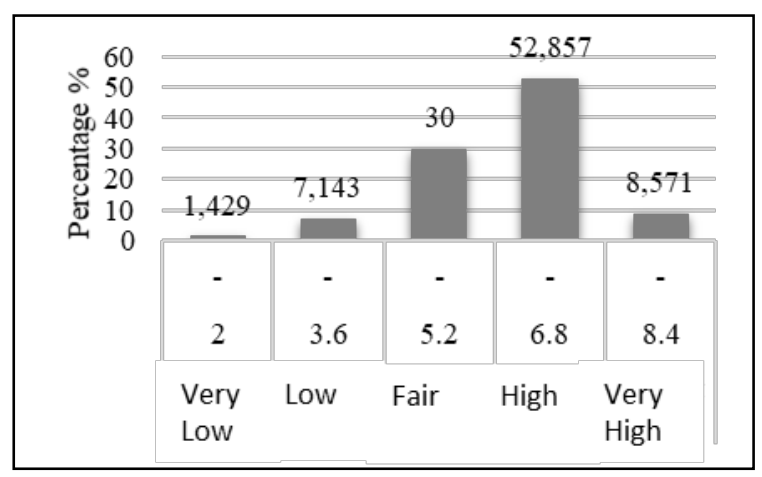

(c) Motivation

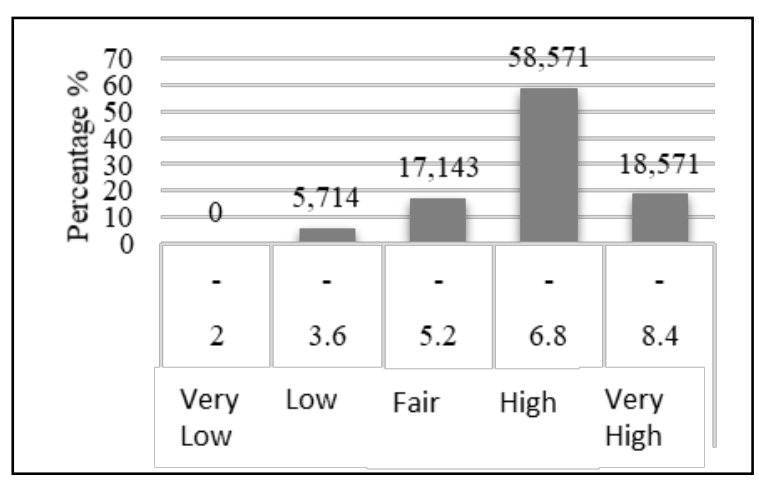

(e) Teamwork jobs has not been running smoothly. Students and teachers provide mutual motivation to achieve the teaching factory learning objectives. Teachers offer opportunities for students to innovate on products to be made. Teamwork is carried out to practice problem-solving in students, and not all teachers do an apprenticeship in the product or service industry. It can be seen in figure 7, which shows the average results of each measurement aspect in human resource parameters. From the discussion, it can be concluded that the implementation of a teaching factory at State Vocational High School 5 Surakarta in the Field of Construction and Property Technology Expertise in terms of source parameters human power is effective.

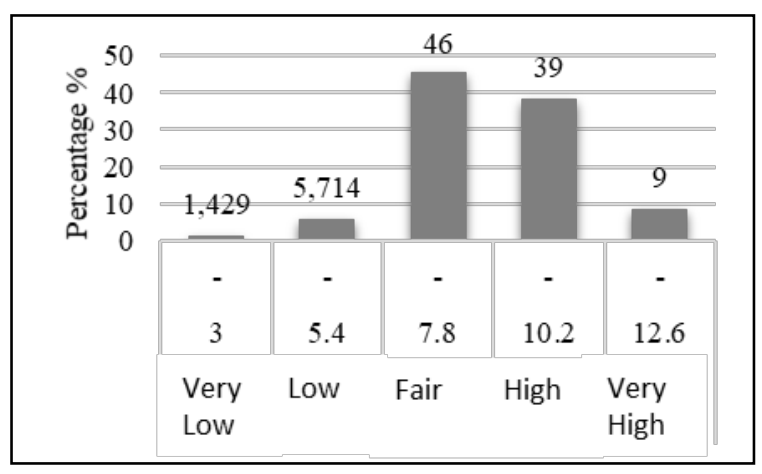

(b) Number and Suitability of Human Resources to Run Teaching Factory

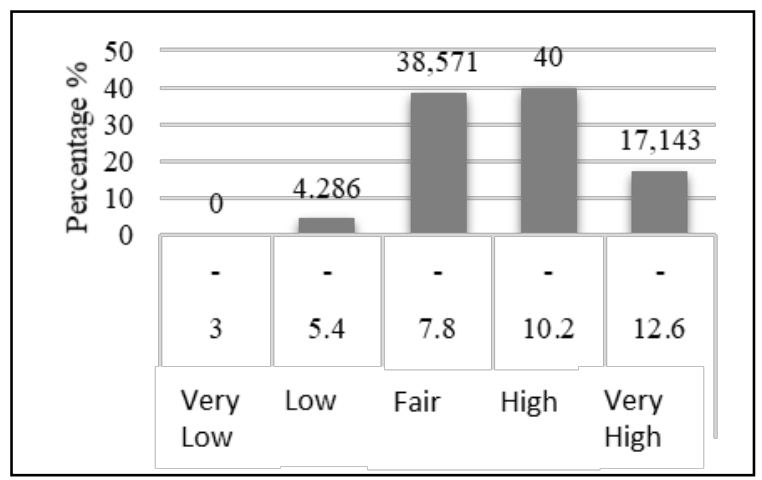

(d) Innovation

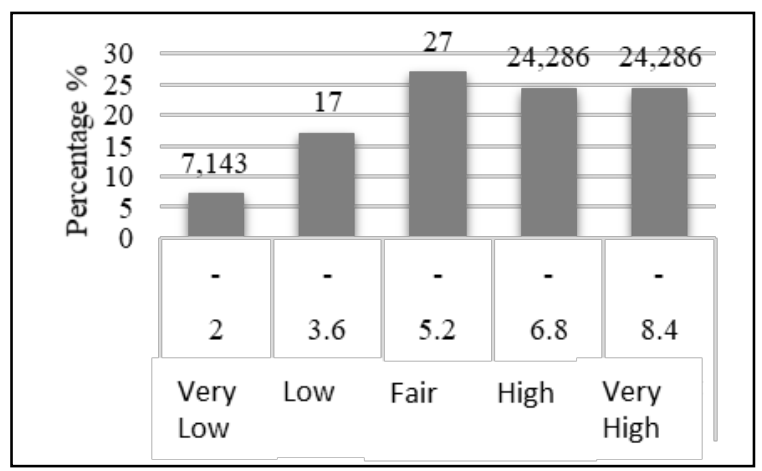

(f) Training for Internal Member

Figure 7. Human Resource Parameters 


\subsection{Laboratories Parameters}

Based on the questionnaire results from the five sub-parameters of laboratory parameters, the mean effectiveness score was 71.72 , categorized as a relatively effective level of achievement.

The management of the use of tools at State Vocational High School 5 Surakarta in the field of expertise in Construction and Property Technology for borrowing tools and tool inventory has been implemented and recorded quite effectively. The equipment maintenance management, tool repair, and calibration (tool checking process) are well structured to monitor the quality of tools, including routine machine maintenance plans, clear responsibility, facilities must be clean, standard, and ready to use. Furthermore, there must be a maintenance card on the machine, Maintenance, Repair, and Calibration (MRC) history data. The MRC management is carried out every three months, and MRC implementation is carried out according to the level of damage to existing equipment. MRC management at State Vocational High School 5 Surakarta has been structured quite effectively because of

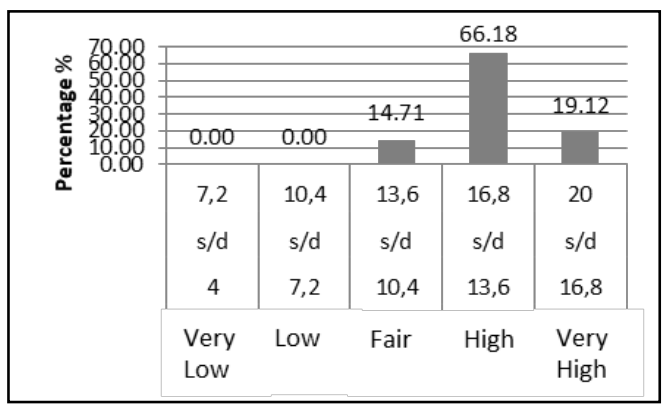

(a) Tools

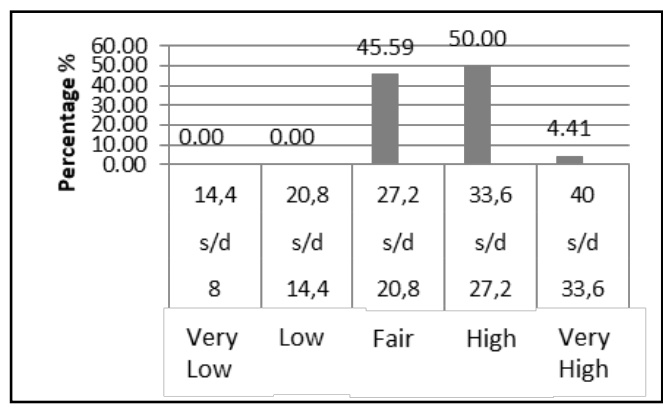

(c) Management Maintenance, Repair, and Calibration (MRC) a clear person in charge, facilities are clean and ready to use, availability of a maintenance card in each machine, and the MRC history data. The arrangement of the workshop must fulfil its function and be neatly arranged according to its competence. The arrangement of workshop space at State Vocational High School 5 Surakarta in the field of construction and property technology expertise is not yet entirely in line with the industrial world, where the workshop space is not wide enough so that students during practice are not entirely indoors but in the front yard of the workshop room. Every room and type of work must be equipped with Occupational Health and Safety (K3) signs, the availability of a fire extinguisher, and a first aid kit. It can be seen in figure 8 , which shows the average results of each measurement aspect in the workshop-lab parameters. From the results, it can be concluded that the teaching factory's performance in terms of workshops at State Vocational High School 5 Surakarta, especially in the area of expertise in Construction and Property Technology, has been effective.

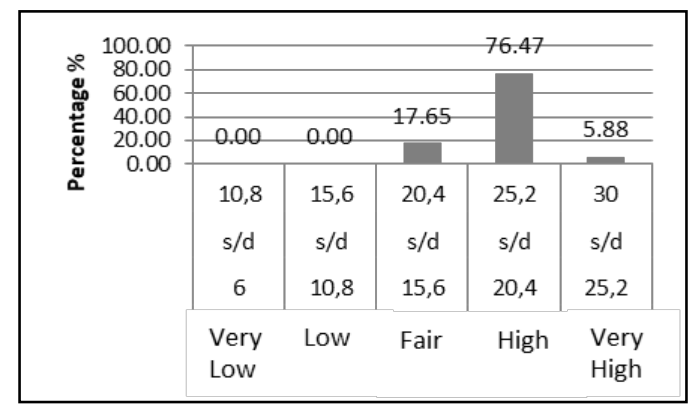

(b) Equipment Use Governance

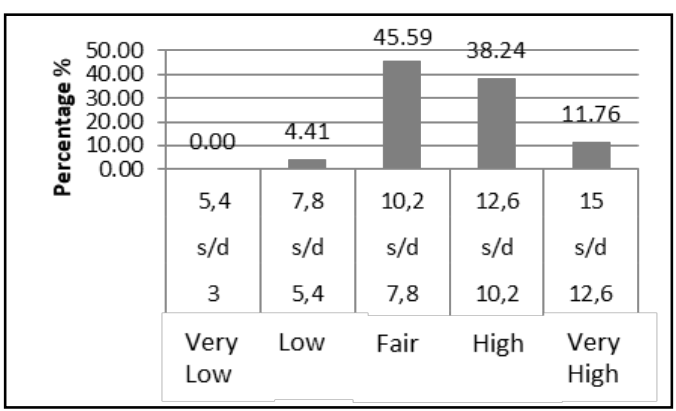

(d) Workshop Layout

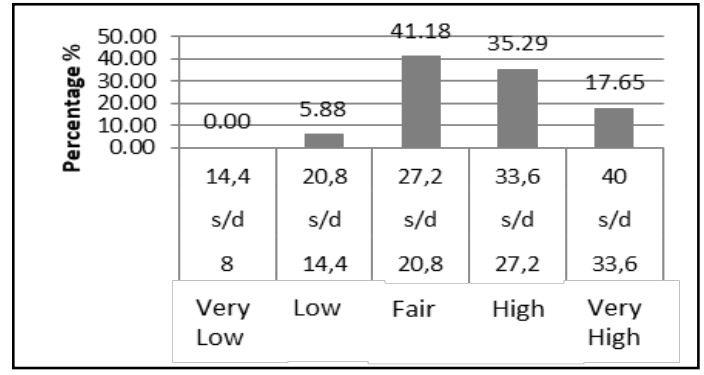

(e) Application of K3

Figure 8. laboratory parameters 


\subsection{Marketing Promotion Parameters}

Based on the questionnaire results from the six sub-parameters of marketing-promotion parameters, the average effectiveness score was 71.24 , categorized as a relatively effective achievement level.

The use of communication media for teaching factory which is used to reach the market namely is using social media, so as to facilitate consumers in ordering products or services; there is already a means to promote product results, but the only means used are the WhatsApp and Instagram social media applications, because there is no official website regarding teaching factory in the field of expertise; availability of clear market coverage; market reach is still around residency of Surakarta, because there is no plan to increase market reach; establishing

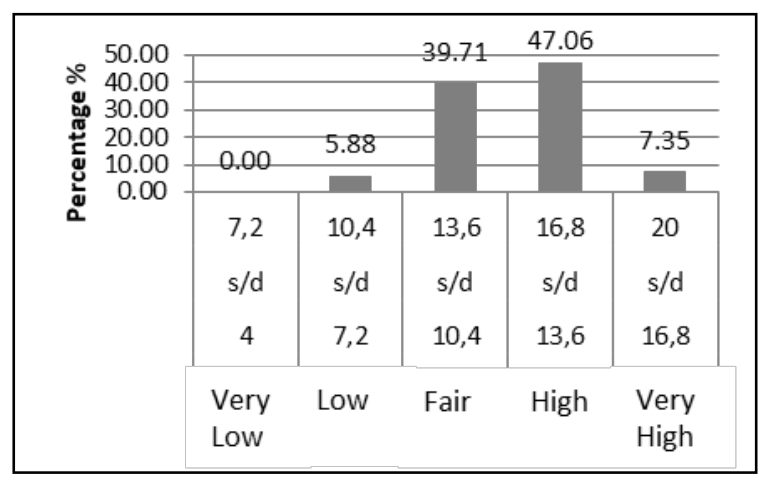

(a) Marketing and Promotion Plan

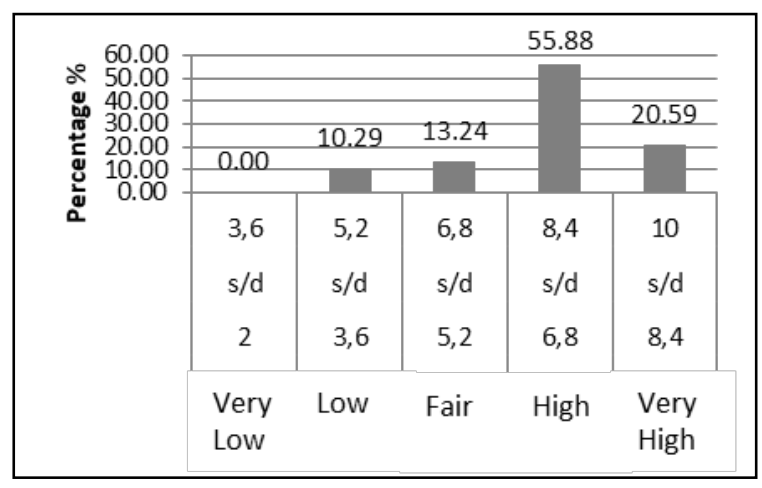

(c) Brochures/Leaflets/Other Tools (Website, CD)

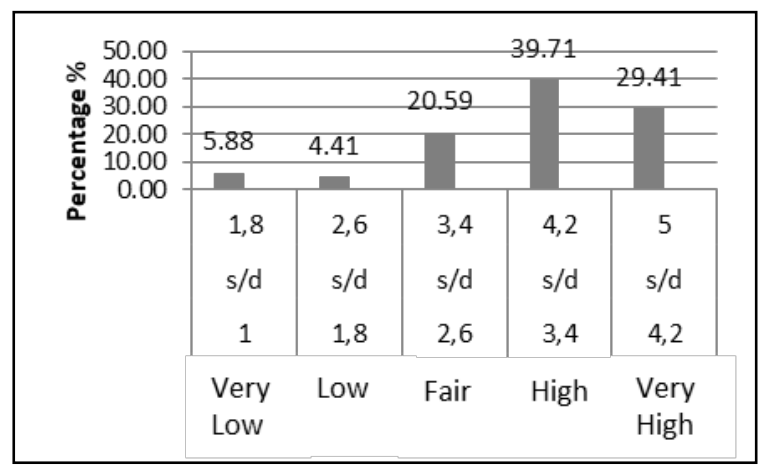

(e) Market Reach relationships with the industrial world; connection with the industrial world has been set but it is still limited to industrial work practices; availability of mock-ups or sample products and models to attract buyers; before being promoted, students of State Vocational High School 5 Surakarta in the field of expertise, first make a mock-up or sample product and model which aims to make it easier for consumers to choose the results of the product and service to be ordered. It can be seen in figure 9 that the average results of each measurement aspect in Marketing-Promotion parameters. From the results, it can be concluded that the teaching factory's performance in terms of marketing-promotion at State Vocational High School 5 Surakarta, especially in the area of expertise in Construction and Property Technology, has been effective.

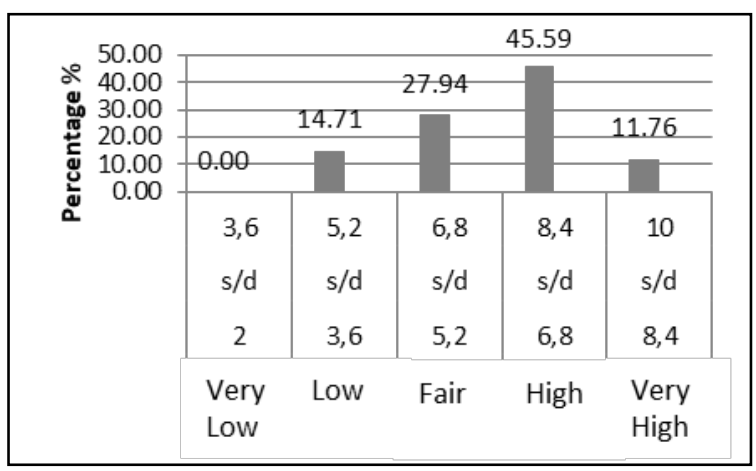

(b) Communication Media for Teaching Factory

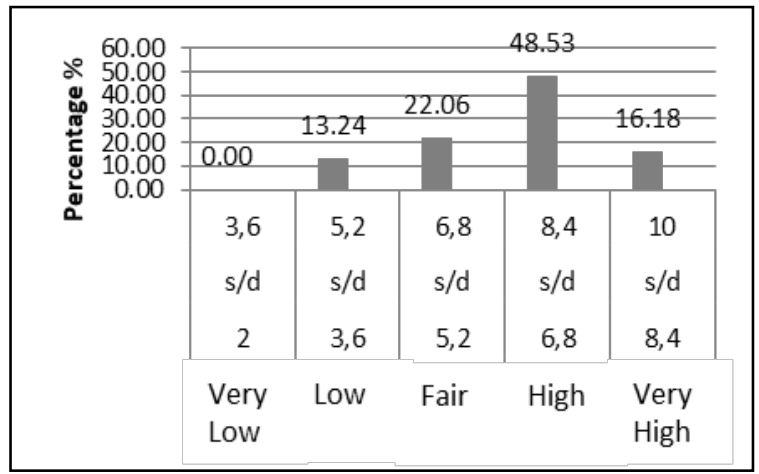

(d) Mock-up/Model

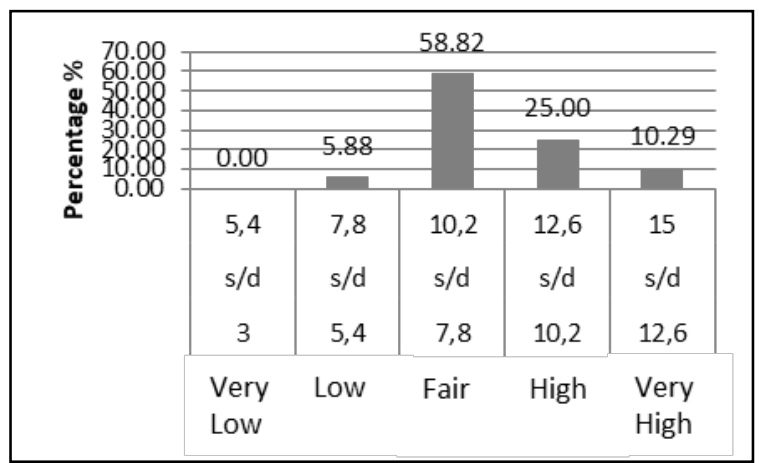

(f) Person in Charge

Figure 9. Marketing-Promotion Parameters 


\subsection{Product-Service Parameters}

Based on the results of the questionnaire from the product-service parameters regarding the six sub-parameters, it was found that the mean effectiveness score was 70.60, categorized in the level of achievement that was quite effective.

The formation of a team responsible for managing orders from consumers and handling input on work results is needed. However, in State Vocational High School 5 Surakarta's expertise, there has not been a team in charge of managing orders from consumers and handling complaints about work results. The product or service quality must meet the needs and be accepted by the market. The quality of the resulting service products has met the requirements. The market takes it because the quality is considered even though the price offered is lower than other industries' prices. The results of the product or service must be consistent or appropriate in terms of quality. The wood's quality is classified as good

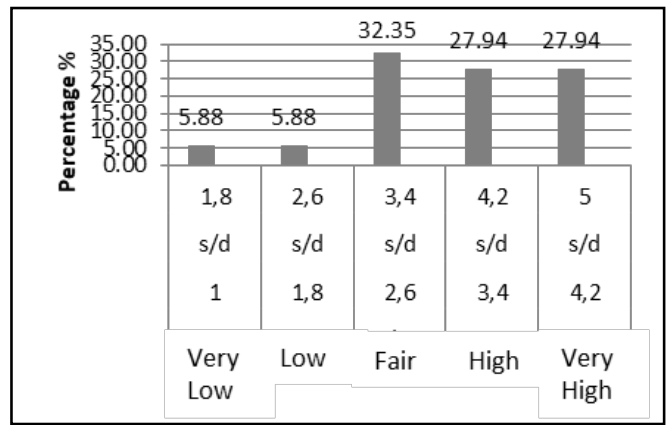

(a) Internal Needed Product - Service

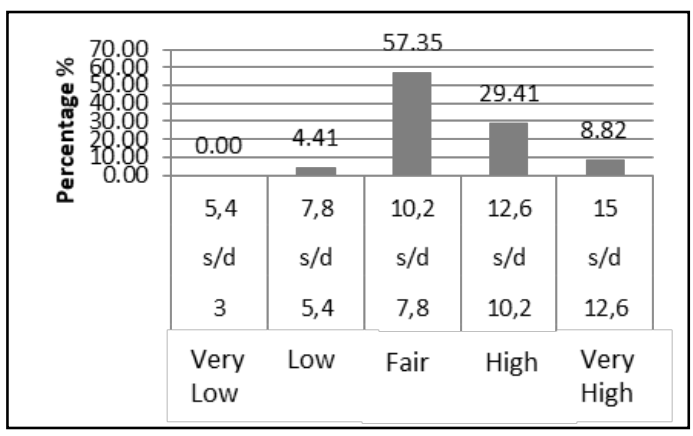

(c) Delivery

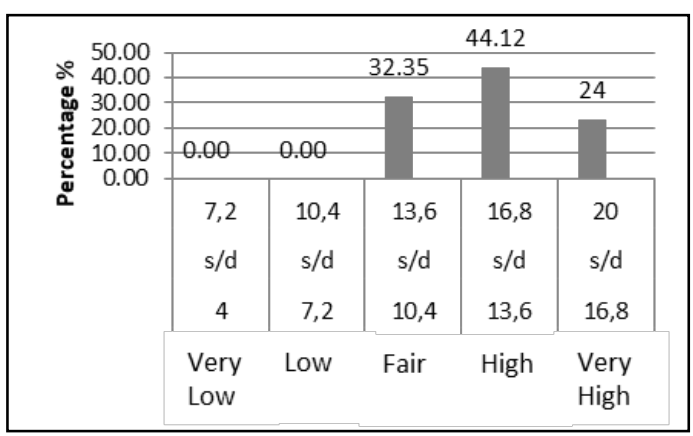

(e) Quality Control in terms of materials for making products or services using teak wood. It shows that the results of students' products are finished and guaranteed in terms of quality. The vocational high school can make discoveries to produce a different product from existing products as a vocational high school work characteristic. The innovation has been carried out to create a different product as a characteristic of the vocational high school work, but just designs from teachers and students who carry out production activities. Students' products include chaise lounges, folding chairs, folding tables, and wooden suitcases. It can be seen in figure 10 that shows the average result of each measurement aspect in Product-Service parameters. From the results, it can be concluded that the teaching factory's performance in terms of products and services at State Vocational High School 5 Surakarta, especially in the field of expertise in Construction and Property Technology, has been effective.

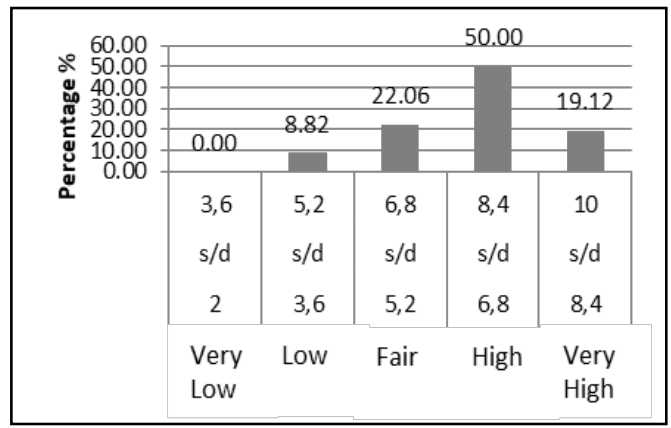

(b) market acceptance

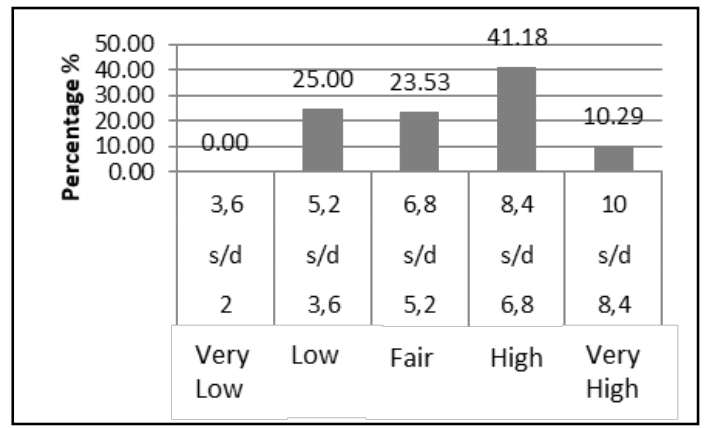

(d) Quality

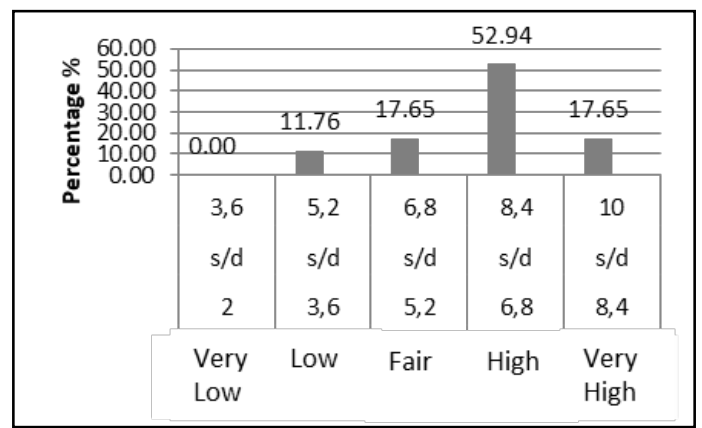

(f) Product Innovation/Diversification

Figure 10. Product-Service Parameters 


\subsection{Legal Aspect}

Based on the questionnaire results regarding the legal aspect sub parameters, the effectiveness average was 66.761, which is included in the achievement level as quite effective.

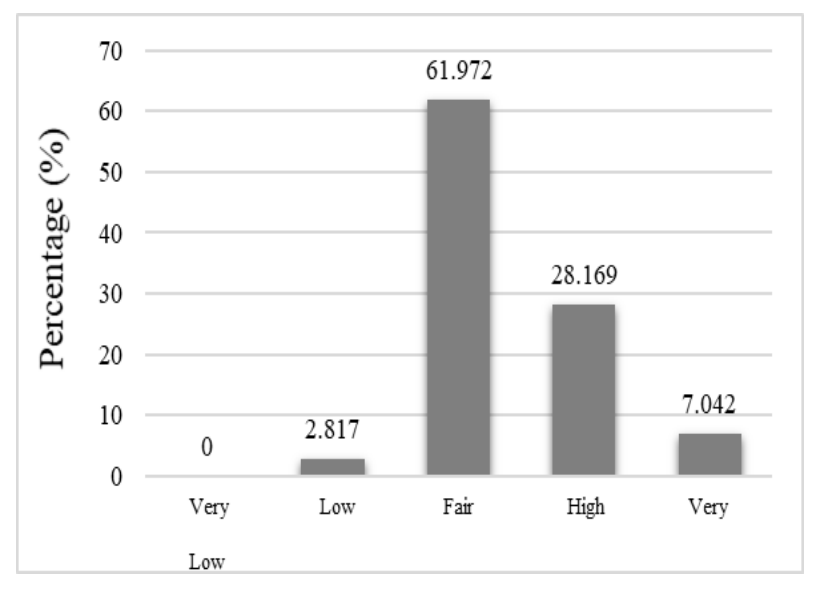

Figure 11. Aspect Legal Parameters

State Vocational High School 5 Surakarta has received a decision from the Ministry of Education and Culture to use the teaching factory learning system. Currently, State Vocational High School 5 Surakarta is in the process of pioneering a teaching factory school. The area of expertise has already used the teaching factory learning system. However, it is not yet entirely from a legal aspect because it is still moving towards the teaching factory program. Nevertheless, the field of expertise has already received revitalization or reconstruction funds from the Ministry of Education and Culture for a Wood Workshop. It can be seen in figure 11, which shows the measurement results in the parameters of the legal aspect. From the results, it can be concluded that the teaching factory's performance in the field of construction and property technology expertise at State Vocational High School 5 Surakarta in terms of legal aspects has been effective.

\subsection{Parameter Analysis}

Based on the questionnaire results regarding the eight parameters above, the average effectiveness of the teaching factory implementation at State Vocational High School 5 Surakarta is 70.292 , which is included in the achievement level as quite effective. It can be concluded that the implementation of the teaching factory in the field of expertise in Construction and Property Technology at State Vocational High School 5 Surakarta has been effective. The average effectiveness of the teaching factory implementation on each parameter can be seen in figure 12 below.

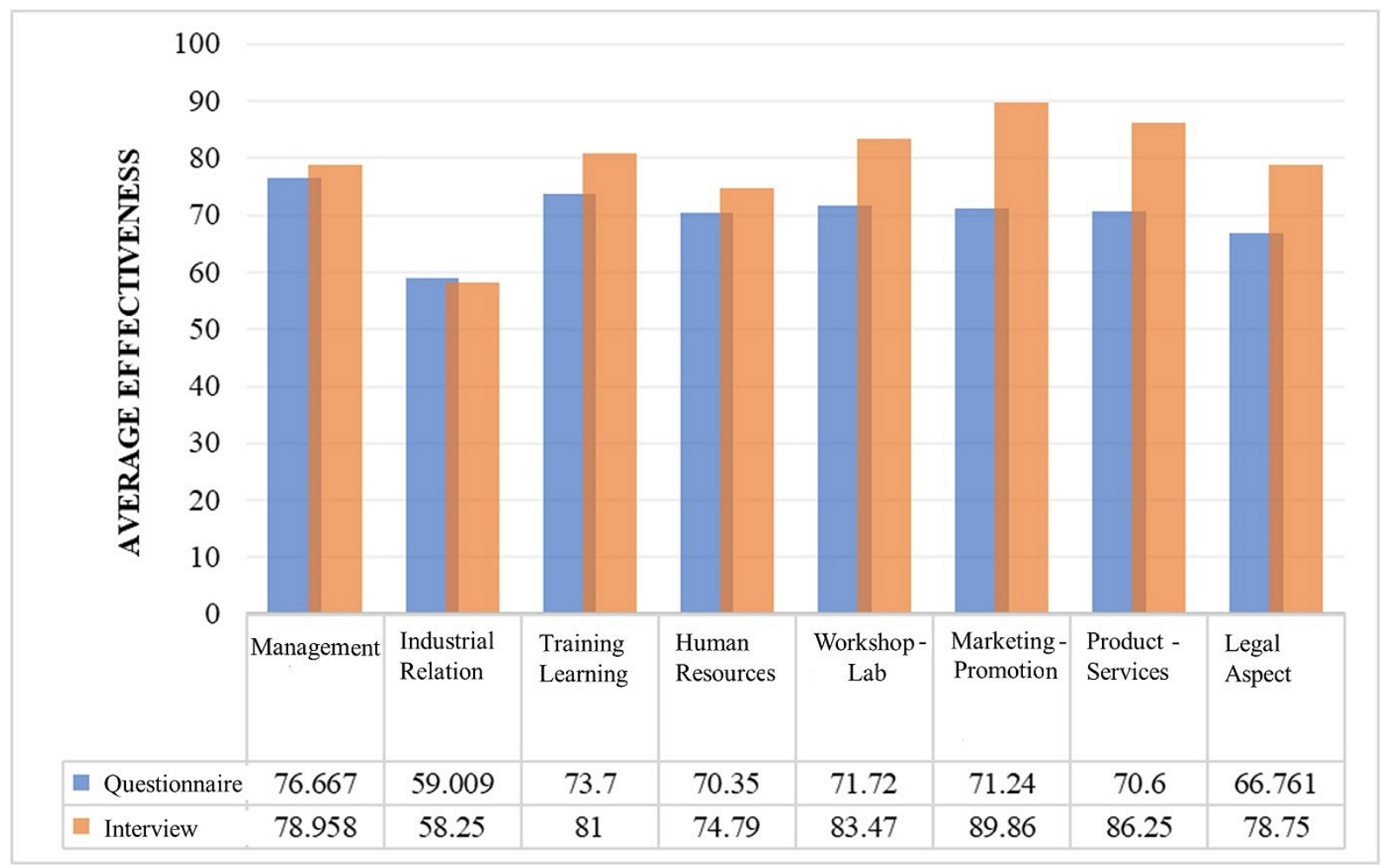

Figure 12. The Effectiveness of the Implementation of Teaching Factory at State Vocational High School 5 Surakarta 
However, it can be seen that the value of the effectiveness of industrial relations parameters for quantitative and qualitative analysis is below 60. This shows that although the overall implementation of the teaching factory has been effective, there are still problems that need to be addressed. In addition, this also shows that the lack of cooperation between schools and industry creates gaps in the implementation of vocational education. Several aspects can be improved to improve this, including the form of cooperation with industry, technology transfer, work projects, and investment from industry in schools.

\section{Conclusions}

Teaching factory learning is a product and service-based learning model in SMK that refers to industry standards and procedures and is carried out in an atmosphere like in an industry. Implementing the Teaching factory at SMK can be carried out if all parameter aspects get a high achievement value. This model is used as an effective learning tool to improve industry-standard competencies. This research refers to the teaching factory's parameters, such as training learning patterns, human resources, workshops-labs, marketing promotions, products-services, management, industrial relations, and legal aspects. There are two research methods used in this research, questionnaire and documentation. Based on the questionnaire results regarding eight parameters, the average effectiveness of the teaching factory implementation at State Vocational High School 5 Surakarta is 70.292, which is included in the achievement level as quite effective. Although it is seen that the average research is effective, there is one aspect of the parameter that has not been effective, namely industrial relations. The transfer of technology and investment by industry has not been implemented between the vocational high school and industry. Nevertheless, the study's overall results concluded that the teaching factory's implementation in the field of expertise in Construction and Property Technology at State Vocational High School 5 Surakarta was effective.

\section{REFERENCES}

[1] UNDP, "Human Development Reports (HDR) 2020," Human Development Report Office, 2020. http://hdr.undp.org/en/\%0Ahttp://hdr.undp.org/en(accessed Dec. 10, 2020).

[2] World Economic Forum, The Global Human Capital Report 2017: Preparing for the future of work. 2017.

[3] D. Mavrikios, K. Georgoulias, and G. Chryssolouris, "The Teaching Factory Network: A new collaborative paradigm for manufacturing education," Procedia Manuf., vol. 31, pp. 398-403, 2019, doi: 10.1016/j.promfg.2019.03.062.

[4] M. B. Triyono, "The Indicators of Instructional Design for E- learning in Indonesian Vocational High Schools," Procedia-Soc. Behav. Sci., vol. 204, no. November 2014, pp. 54-61, 2015, doi: 10.1016/j.sbspro.2015.08.109.

[5] Suharno, N. A. Pambudi, and B. Harjanto, "Vocational education in Indonesia: History, development, opportunities, and challenges," Child. Youth Serv. Rev., vol. 115, no. May, p. 105092, 2020, doi: 10.1016/j.childyouth.2020.105092.

[6] Central Bureau of Statistics, "Indonesian Labor Situation February 2020,” Jakarta, 2020.

[7] Directorate of Vocational High School Development, "Outlines of the 2012 Vocational School Development Program," Jakarta, 2012.

[8] A. Saptono, A. Wibowo, B. S. Narmaditya, R. P. D. Karyaningsih, and H. Yanto, "Does entrepreneurial education matter for Indonesian students' entrepreneurial preparation: The mediating role of entrepreneurial mindset and knowledge," Cogent Educ., vol. 7, no. 1, 2020, doi: 10.1080/2331186X.2020.1836728.

[9] Minister of Education, Regulation of the Minister of Education and Culture of the Republic of Indonesia Number 40 of 2008 concerning Standard of Facilities and Infrastructure for Vocational High Schools/Madrasah Aliyah Vocational Schools (SMK/MAK). Indonesia, 2008.

[10] K. K. Vijayan, O. J. Mork, and L. A. L. Giske, "Integration of a Case Study into Learning Factory for Future Research," Procedia Manuf., vol. 31, pp. 258-263, 2019, doi: 10.1016/j.promfg.2019.03.041.

[11] P. Stavropoulos, H. Bikas, and D. Mourtzis, "Collaborative Machine Tool design: The Teaching Factory paradigm," Procedia Manuf., vol. 23, no. 2017, pp. 123-128, 2018, doi: 10.1016/j.promfg.2018.04.004.

[12] A. L. Andersen, T. D. Brunoe, and K. Nielsen, "Engineering education in changeable and reconfigurable manufacturing: Using problem-based learning in a learning factory environment," Procedia CIRP, vol. 81, pp. 7-12, 2019, doi: 10.1016/j.procir.2019.03.002.

[13] G. Chryssolouris, D. Mavrikios, and L. Rentzos, "The Teaching Factory: A Manufacturing Education Paradigm," Procedia CIRP, vol. 57, pp. 44-48, 2016, doi: 10.1016/j.procir.2016.11.009.

[14] L. Louw and Q. Deacon, "Teaching Industrie 4.0 technologies in a learning factory through problem-based learning: Case study of a semi-automated robotic cell design," Procedia Manuf., vol. 45, pp. 265-270, 2020, doi: 10.1016/j.promfg.2020.04.105.

[15] D. Mavrikios, K. Georgoulias, and G. Chryssolouris, "The Teaching Factory Paradigm: Developments and Outlook," Procedia Manuf., vol. 23, no. 2017, pp. 1-6, 2018, doi: 10.1016/j.promfg.2018.04.029.

[16] L. Rentzos, M. Doukas, D. Mavrikios, D. Mourtzis, and G. Chryssolouris, "Integrating manufacturing education with industrial practice using teaching factory paradigm: A construction equipment application," Procedia CIRP, vol. 
17, pp. 189-194, 2014, doi: 10.1016/j.procir.2014.01.126.

[17] J. L. Jooste et al., "Teaching maintenance plan development in a learning factory environment," Procedia Manuf., vol. 45, pp. 379-385, 2020, doi: 10.1016/j.promfg.2020.04.040.

[18] Directorate of Vocational High School Development, Teaching Factory Implementation Guide. Jakarta: Ministry of Education and Culture, 2017.

[19] B. J. Ralph, A. Schwarz, and M. Stockinger, "An implementation approach for an academic learning factory for the metal forming industry with special focus on digital twins and finite element analysis," Procedia Manuf., vol. 45, pp. 253-258, 2020, doi: 10.1016/j.promfg.2020.04.103.

[20] L. F. Leal, A. Fleury, and E. Zancul, "Starting up a learning factory focused on industry 4.0," Procedia Manuf., vol. 45, pp. 436-441, 2020, doi: 10.1016/j.promfg.2020.04.049.

[21] Ministry of Education and Culture, Building Indonesian Vocational Secondary Education: A Roadmap to 2030. Jakarta: Deutsche Gesellschaft für Internationale Zusammenarbeit (GIZ) GmbH, 2016.

[22] ATMI-BizDec, "Teaching Factory Coaching Programme," Jakarta, 2015.
[23] M. Henri, M. D. Johnson, and B. Nepal, "A Review of Competency-Based Learning: Tools, Assessments, and Recommendations," J. Eng. Educ., vol. 106, no. 4, pp. 607638, 2017, doi: $10.1002 /$ jee.20180.

[24] H. Sutarto, "Articulation of High Order Thinking Skills in Competency-Based Instruction in Indonesia Vocational and Technical High School," Adv. Soc. Sci. Educ. Humanit. Res., vol. 102, pp. 211-217, 2017, doi: 10.2991/ictvt-17.2017.36.

[25] H. B. Lund and A. Karlsen, "The Importance of Vocational Education Institutions in Manufacturing Regions: Adding Content to a Broad Definition of Regional Innovation Systems," Ind. Innov., vol. 27, no. 6, pp. 660-679, 2019, doi: https://doi.org/10.1080/13662716.2019.1616534.

[26] L. Rentzos, D. Mavrikios, and G. Chryssolouris, “A two-way knowledge interaction in manufacturing education: The teaching factory," Procedia CIRP, vol. 32, no. Clf, pp. 31-35, 2015, doi: 10.1016/j.procir.2015.02.082.

[27] N. Luh Ayu Kartika Yuniastari S and R. K. Wiyati, "Measuring the level of effectiveness and efficiency of the Eresearch STIKOM Bali system," Natl. Conf. Syst. Informatics, pp. 9-10, 2015. 